\title{
Women and myocardial infarction: agism rather than sexism?
}

\author{
J N Adams, M Jamieson, J M Rawles, R J Trent, K P Jennings
}

\begin{abstract}
Objective-To determine whether women with myocardial infarction are treated difierently from men of the same age and to aseses the effect of changes in the coronary care unit admission policy.

Design-Clinical audit.

Setting-The coronary care unit and
\end{abstract} general medical wards of a teaching hospital. In 1990 the age limit for admission to coronary care was 65 years. This age limit was removed in 1991.

Patients-539 female and 977 male patients admitted with myocardial infarction between 1990 and 1992.

Main outcomes-Admiseion to the coronary care unit, administration of thrombolysis, and in-hospital mortality.

Results-409 men and 254 women were admitted with myocardial infarction in 1990 and 568 men and 285 women in 1992. Removal of the age limit for admission to the coronary care unit resulted in an increase in the numbers of both seres admitted with myocardial infarction. In both years, however, proportionately more men with infarction were admitted to coronary care: 226 men (55\%) and 96 women (38\%) (P < 0.01) (95\% CI 7 to 28$)$ in 1990 and 459 men $(81 \%)$ and 200 women $(70 \%)(P<0.01)(\% C I 2$ to 19$)$ in 1992. Some 246 men $(60 \%)$ and 133 women (52\%) with infarction $(P<0.01)$ received thrombolytic treatment in 1990 compared with 319 men $(56 \%)$ and 130 women (46\%) $(P<0.01)$ in 1992 . The mean age of women sustaining a myocardial infarction was significantly greater in both years studied. In 1992 a total of 78 men (7\%) and 34 women (4\%) $(P<0.05)$ admitted with chest pain underwent cardiac catheterisation before discharge from hospital.

Conclusions-Differences in admission rates to the coronary care unit and the rate of thrombolysis between the sexes can be explained by the older age of women sustaining infarction. The application of age limits for admission to coronary care or administration of thrombolysis places elderty patients at a disadvantage. As women sustain myocardial infarctions at an older age they are placed at a greater disadvantage.

\section{(Br Heart f 1995;73:87-91)}

Keywords: myocardimantinction, agism, sexiom.

Several studies: from the United States ${ }^{12}$ and more recently from the United Kingdom ${ }^{34}$ have shown that women with coronary artery disease are proportionately less likely to undergo cardiac catheterisation and coronary artary surgery than men. Although the incidence of coronary artery disease is higher in men, it is nevertheless the leading cause of death in women. After myocardial infarction the death rate for women is higher than for men. Some studies suggest that this is because women sustain infarcts at an older age than men $^{56}$ and others that it is a gender related difference. ${ }^{78} \mathrm{~A}$ third contributing factor to the high mortality could be that women with myocardial infarction are treated differently. The aim of this study was to establish whether women admitted with myocardial infarction in the Grampian region were treated differently to their male counterparts. It was also the objective of this study to ascertain the effect of changes in the coronary care unit admissions policy on the management of women with myocardial infarction.

\section{Patients and methods}

In Grampian region all patients with a suspected myocardial infarction are admitted to Aberdeen Royal Infirmary. Before 1991 it was the coronary care unit policy to accept only patients with suspected infarction under the age of 65 years, however, this policy was reviewed in 1991 and the age limit removed. Details of all patients admitted to the medical wards and coronary care unit with a history of chest pain between 1990 and 1992 were recorded by a cardiac research nurse. These patients were followed up throughout their hospital stay and all details recorded on computer. Patients were considered to have 

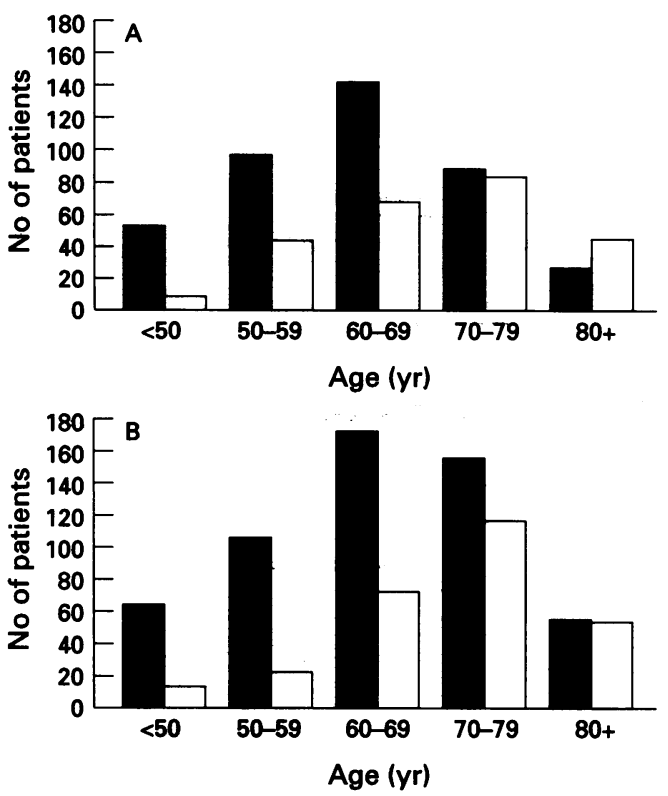

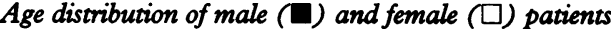
with a definite infarction admitted to the coronary care unit in (A) 1990 and (B) 1992.

sustained an acute myocardial infarction if they presented with a clinical history consistent with infarction and developed new pathological $Q$ waves on an electrocardiogram (ECG) and/or a twofold rise in cardiac enzymes (aspartate aminotransferase and lactate dehydrogenase). From this database it was possible to study differences in the management of men and women with confirmed myocardial infarction and the effect of the change in the coronary care admissions policy on these differences. Statistical comparisons were made using an unpaired Student's $t$ test.

Criteria for the administration of thrombo- lysis was the same in both the coronary care unit and medical wards. In 1990 all patients admitted within $24 \mathrm{~h}$ of onset of pain consistent with infarction received thrombolysis provided they had no contraindications. In 1992 only patients admitted within $6 \mathrm{~h}$ of onset and with ST elevation on the ECG received thrombolytic treatment.

\section{Results}

ADMISSION TO CORONARY CARE

Of a total of 898 male (61\%) and 575 female $(39 \%)$ patients with chest pain who were admitted to either the coronary care unit or a medical ward in 1990, 409 men (46\%) and 254 women (44\%) had a confirmed myocardial infarction. In 1992 a total of 1169 men (59\%) and 798 women (41\%) with chest pain were admitted and of these 568 men (49\%) and 285 women $(36 \%)$ had a confirmed infarction $(P<0.01)$. In both years female patients with confirmed myocardial infarction were significantly older: the mean age for women being 69 years in 1990 and 71 years in 1992 compared with 63 years and 65 years in the same years for men $(P<0.01)$. For those patients with a definite infarction who were admitted to the coronary care unit the mean age was 57 years for men and 62 years for women in 1990 and 63 years and 68 years respectively in 1992. The figure shows the age distribution for all patients with confirmed myocardial infarction admitted to either the coronary care or a general medical ward for the two years.

Tables 1 and 2 show the number of male and female patients with chest pain admitted to the coronary care unit and a general medical ward and the number who sustained a confirmed infarction in 1990 and 1992. A total of $322(49 \%)$ of the patients with confirmed infarction were admitted or transferred

Table 1 Number of patients with myocardial infarction and those who received thrombolytic treatment by ward of admission in 1990

\begin{tabular}{|c|c|c|c|c|c|c|}
\hline & \multicolumn{2}{|c|}{ Cononary care unit } & \multirow[b]{2}{*}{ Pvalue } & \multicolumn{2}{|c|}{ General medical wards } & \multirow[b]{2}{*}{ Pvalue } \\
\hline & $\begin{array}{l}\text { Men } \\
(n=480)\end{array}$ & $\begin{array}{l}\text { Women } \\
(n=201)\end{array}$ & & $\begin{array}{l}\text { Men } \\
(n=418)\end{array}$ & $\begin{array}{l}\text { Women } \\
(n=374)\end{array}$ & \\
\hline $\begin{array}{l}\text { Confirmed acute myocardial } \\
\text { infarction }(\%)\end{array}$ & $226(47)$ & $96(48)$ & NS & $183(44)$ & $158(42)$ & NS \\
\hline $\begin{array}{l}\text { Thrombolysis in acute } \\
\text { myocardial infarction (\%) }\end{array}$ & $148(65)^{\star}$ & $64(67)^{\star \star}$ & NS & $98(54)^{\star}$ & $69(44)^{\star \star}$ & NS \\
\hline
\end{tabular}

NS, not significant. ${ }^{\star} P<0.05 ;{ }^{\star \star} P<0.01$.

Table 2 Number of patients with myocardial infarction and those who received thrombolytic treatment by zoard of admission in 1992

\begin{tabular}{|c|c|c|c|c|c|c|}
\hline & \multicolumn{2}{|c|}{ Coronary care unit } & \multirow[b]{2}{*}{$P$ value } & \multicolumn{2}{|c|}{ General medical wards } & \multirow[b]{2}{*}{ Pvalu } \\
\hline & $\begin{array}{l}\text { Men } \\
(n=877)\end{array}$ & $\begin{array}{l}\text { Women } \\
(n=432)\end{array}$ & & $\begin{array}{l}\text { Men } \\
(n=292)\end{array}$ & $\begin{array}{l}\text { Women } \\
(n=366)\end{array}$ & \\
\hline $\begin{array}{l}\text { Confirmed acute myocardial } \\
\text { infarction (\%) }\end{array}$ & $459(52)$ & $200(46)$ & $<0.05$ & $109(29)$ & $85(23)$ & NS \\
\hline $\begin{array}{l}\text { Thrombolysis in acute myocardial } \\
\text { infacrction (\%) }\end{array}$ & $282(61)^{\star}$ & $112(56)^{\star \star}$ & NS & $37(34)^{\star}$ & $18(21)^{\star \star}$ & NS \\
\hline
\end{tabular}

NS, not significant. ${ }^{\star} P<0.01 ;{ }^{\star \star} P<0.01$. 
Table 3 Differences in rate of admission to cononary care for patients with confirmed infarction by age and sex

\begin{tabular}{|c|c|c|c|c|c|c|}
\hline \multirow[b]{2}{*}{ Age (years) } & \multicolumn{3}{|l|}{1990} & \multicolumn{3}{|l|}{1992} \\
\hline & $\operatorname{Men}(\%)$ & Women (\%) & $\begin{array}{l}\text { P value } \\
(95 \% C I)\end{array}$ & $\operatorname{Men}(\%)$ & Women (\%) & $\begin{array}{l}\text { P value } \\
\text { (95\%CD) }\end{array}$ \\
\hline $\begin{array}{l}<50 \\
50-59 \\
60-69 \\
70-79 \\
>80\end{array}$ & $\begin{array}{l}47(86) \\
86(89) \\
72(51)^{\star} \\
18(21)^{\star} \\
3(11)^{\star}\end{array}$ & $\begin{array}{c}8(73) \\
38(84) \\
29(42)^{\star} \\
15(18)^{\star} \\
6(13)^{\star}\end{array}$ & $\begin{array}{l}\text { NS } \\
\text { NS } \\
\text { NS } \\
\text { NS } \\
\text { NS }\end{array}$ & $\begin{array}{r}64(97) \\
101(93) \\
151(85) \\
123(77) \\
20(35)\end{array}$ & $\begin{array}{l}14(100) \\
21(88) \\
65(88) \\
84(71) \\
16(29)\end{array}$ & $\begin{array}{l}\text { NS } \\
\text { NS } \\
\text { NS } \\
\text { NS } \\
\text { NS }\end{array}$ \\
\hline Total & $226(55)$ & $96(38)$ & $\begin{array}{l}<0.01 \\
(7 \text { to } 28)\end{array}$ & $459(81)$ & $200(70)$ & $\begin{array}{l}<0.01 \\
(2 \text { to } 19)\end{array}$ \\
\hline
\end{tabular}

NS, not significant.

* Patients over the age of 65 years could be admitted to the coronary care unit on clinical grounds at the discretion of the admitting physician.

to the coronary care unit in 1990 and this figure rose in 1992 to $659(77 \%)(P<0.01)$. Some $96(30 \%)$ of the patients with a definite myocardial infarction admitted to the coronary care unit in 1990 were female and in 1992 this proportion remained unchanged with 200 women (30\%) of 659 patients with infarction. Table 3 shows the rates of admission to the coronary care unit for patients with infarction by age group.

Of the patients admitted with chest pain but who subsequently did not sustain an infarction, 254 men (52\%) and 105 women $(33 \%)(\mathbf{P}<0.01)$ were admitted or transferred to coronary care in 1990 compared with 418 men $(70 \%)$ and 232 women (45\%) $(P<0.01)$ in 1992.

\section{THROMBOLYSIS}

Of the patients with confirmed infarction, 379 $(57 \%)$ in 1990 and $449(53 \%)$ in 1992 received thrombolytic treatment. In each year the proportion of women with confirmed myocardial infarction receiving thrombolysis was significantly lower than men: 246 men (60\%) compared with 133 women $(52 \%)$ $(P<0.01)$ in 1990 and 319 men $(56 \%)$ and 130 women (46\%) $(P<0.05)$ in 1992 (table 4). Administration of thrombolytic treatment was less in general medical wards than in the coronary care unit (tables 1 and 2). There was a significant reduction in the use of thrombolytic agents in the general medical wards between 1990 and $1992(P<0.01)$, but no such change occurred within the coronary care unit. Of those patients admitted to the coronary care unit with a confirmed infarction, there was no significant difference in the rate of thrombolysis between the two sexes for either year. Of those patients with confirmed infarction admitted to the coronary care unit in 1990,145 men $(64 \%)$ and 70 women (73\%) had ST elevation of greater than $1 \mathrm{~mm}$ in the limb leads or $2 \mathrm{~mm}$ in precordial leads on the admission ECG. ST elevation was present on the admission ECG of 89 men (49\%) and 84 women (53\%) with confirmed infarction admitted to general medical wards (comparable data were not available for 1992).

\section{IN-HOSPITAL MORTALITY}

Among patients with definite infarction the in-hospital mortality was significantly higher for women in both years, with 54 (21\%) female deaths $v 57(14 \%)$ male $(P=0.02)$ in 1990 and $61(21 \%)$ female deaths $v 84(15 \%)$ male $(P=0.02)$ in 1992 (table 5). There was no difference between the in-hospital mortality for patients admitted or transferred to the coronary care unit and those admitted to general medical wards. The death rates for patients who did not sustain an infarct was much lower, with $10(2 \%)$ male deaths $v$

Table 4 Administration of thrombolytic treatment for all patients with confirmed infarction by age and sex

\begin{tabular}{|c|c|c|c|c|c|c|c|c|c|}
\hline \multirow[b]{2}{*}{$\begin{array}{l}\text { Age } \\
\text { (years) }\end{array}$} & \multicolumn{3}{|l|}{1990} & \multicolumn{3}{|l|}{1992} & \multicolumn{3}{|l|}{ Total } \\
\hline & Men \% & Women (\%) & $\begin{array}{l}P \text { value } \\
(95 \% C D)\end{array}$ & $\operatorname{Men}(\%)$ & Women (\%) & $\begin{array}{l}\text { P value } \\
\text { (95\%CI) }\end{array}$ & Men (\%) & Women (\%) & $\begin{array}{l}\text { Pvalue } \\
(95 \% C I)\end{array}$ \\
\hline $\begin{array}{l}<50 \\
50-59 \\
60-69 \\
70-79 \\
80+\end{array}$ & $\begin{array}{l}36(65) \\
63(65) \\
93(65) \\
44(50) \\
10(37)\end{array}$ & $\begin{array}{r}8(73) \\
33(73) \\
43(62) \\
35(42) \\
14(31)\end{array}$ & $\begin{array}{l}\text { NS } \\
\text { NS } \\
\text { NS } \\
\text { NS } \\
\text { NS }\end{array}$ & $\begin{array}{r}41(62) \\
64(59) \\
108(61) \\
81(51) \\
25(44)\end{array}$ & $\begin{array}{r}8(57) \\
11(46) \\
38(51) \\
58(49) \\
15(28)\end{array}$ & $\begin{array}{l}\text { NS } \\
\text { NS } \\
\text { NS } \\
\text { NS } \\
\text { NS }\end{array}$ & $\begin{array}{r}77(64) \\
127(62) \\
201(63) \\
125(51) \\
35(42)\end{array}$ & $\begin{array}{l}16(64) \\
44(63) \\
81(57) \\
93(46) \\
29(29)\end{array}$ & $\begin{array}{l}\text { NS } \\
\text { NS } \\
\text { NS } \\
\text { NS } \\
\text { NS }\end{array}$ \\
\hline Total & $246(60)$ & $133(52)$ & $\begin{array}{l}<0.01 \\
(0 \text { to } 16)\end{array}$ & $319(56)$ & $130(46)$ & $\begin{array}{l}<0.05 \\
(1 \text { to } 20)\end{array}$ & $565(58)$ & $263(49)$ & $\begin{array}{l}<0.01 \\
(2 \text { to } 16)\end{array}$ \\
\hline
\end{tabular}

NS, not significant.

Table 5 In-hospital mortality for all patients with confirmed infarction by age and sex

\begin{tabular}{|c|c|c|c|c|c|c|c|c|c|}
\hline \multirow[b]{2}{*}{$\begin{array}{l}\text { Age } \\
\text { (years) }\end{array}$} & \multicolumn{3}{|l|}{1990} & \multicolumn{3}{|l|}{1992} & \multicolumn{3}{|l|}{ Total } \\
\hline & Men \% & Women (\%) & $\begin{array}{l}\text { Pvalue } \\
\text { (95\%CI) }\end{array}$ & $\operatorname{Men}(\%)$ & Women (\%) & $\begin{array}{l}\text { Pvalue } \\
\text { (95\%CI) }\end{array}$ & Men (\%) & Women (\%) & $\begin{array}{l}\text { Pvalue } \\
\text { (95\%CI) }\end{array}$ \\
\hline $\begin{array}{l}<50 \\
50-59 \\
60-69\end{array}$ & $\begin{array}{c}3(5) \\
7(7) \\
20(14)\end{array}$ & $\begin{array}{c}0(0) \\
5(11) \\
15(22)\end{array}$ & $\begin{array}{l}\text { NS } \\
\text { NS } \\
\text { NS }\end{array}$ & $\begin{array}{c}0(0) \\
0(0) \\
20(11)\end{array}$ & $\begin{array}{c}2(14) \\
1(4) \\
17(23)\end{array}$ & $\begin{array}{l}\text { NS } \\
\text { NS } \\
<0.05 \\
(10 \text { to } 22)\end{array}$ & $\begin{array}{c}3(2) \\
7(3) \\
40(13)\end{array}$ & $\begin{array}{c}2(8) \\
6(9) \\
32(22)\end{array}$ & $\begin{array}{l}\text { NS } \\
\text { NS } \\
<0.05 \\
(2 \text { to } 18)\end{array}$ \\
\hline $\begin{array}{l}70-79 \\
80+\end{array}$ & $\begin{array}{r}22(25) \\
5(19)\end{array}$ & $\begin{array}{l}22(26) \\
12(27)\end{array}$ & $\begin{array}{l}\text { NS } \\
\text { NS }\end{array}$ & $\begin{array}{l}44(28) \\
20(35)\end{array}$ & $\begin{array}{l}25(21) \\
16(30)\end{array}$ & $\begin{array}{l}\text { NS } \\
\text { NS }\end{array}$ & $\begin{array}{l}66(27) \\
25(30)\end{array}$ & $\begin{array}{l}47(23) \\
28(28)\end{array}$ & $\begin{array}{l}\text { NS } \\
\text { NS }\end{array}$ \\
\hline Total & $57(14)$ & $54(21)$ & $\begin{array}{l}0.02 \\
\text { (1 to } 13)\end{array}$ & $84(15)$ & $61(21)$ & $\begin{array}{l}<0.05 \\
(1 \text { to } 12)\end{array}$ & $141(14)$ & $115(21)$ & $\begin{array}{l}<0.01 \\
(1 \text { to } 12)\end{array}$ \\
\hline
\end{tabular}

NS, not significant. 
seven female deaths (2\%) in 1990 and five ( $1 \%)$ male $v$ nine (2\%) female deaths in 1992.

\section{CARDIAC CATHETERISATION}

Of 78 men $(7 \%)$ and 34 women (4\%) $(P<$ 0.05 ) admitted with suspected myocardial infarction who underwent cardiac catheterisation before discharge from hospital, 21 men (4\%) and nine women (3\%) had sustained confirmed myocardial infarction.

\section{Discussion}

The removal of the age limit for admission to the coronary care unit resulted in a significant rise in the numbers of both men and women admitted to coronary care. In 1990 and 1992 proportionately more men with infarction were admitted to the coronary care unit, but when the Data were stratified for age there was no difference in admission rates within each age group. During 1990 and 1992 women constituted $30 \%$ of the patients with infarction admitted to the coronary care unit, saggesting that while the total number of women admitted to coronary care rose as a result of the removal of the age limit, men with infarction were still more likely to be admitted to the coronary care unit. Removing the age limit for admission to coronary care resulted in a greater number of patients over 65 years of age being admitted to the unit, however, the percentage of older patients with infarction admitted to the coronary care unit was still lower than for patients in their $50 \mathrm{~s}$ and $60 \mathrm{~s}$. This lower rate of admission to coronary care for older patients could be interpreted as agism, but probably also in part reflects the apposite use of limited resources in patients for whom aggressive intervention would be inappropriate.

In this series women with definite infarction received thrombolysis proportionately less often than men. As in previous studies, ${ }^{5-7}$ however, the women presenting with myocardial infarction in this series were on average 6 yearsolder than the men. When the two groups are stratified for age there is no difference in the administration of thrombolysis between the sexes within each age group. A larger proportion of the older age groups was female and the lower rate of thrombolysis in the older patients resulted in overall fewer women receiving this treatment. The results of ISIS $2 \%$ howed that the relative reduction in mortality with thrombolysis was greatest in the older age groups. Older patients should, therefore, not be denied thrombolysis on the grounds of age alone. The reduction in thrombolytic rate with increasing age may be the result of a greater number of patients with contraindications to thrombolysis in this group. In 1990 ST elevation was present on the admission ECG in a similar percentage of male and female patients with infarction. It is unlikely, therefore, that a bias in thrombolysis rates would arise because of differences in ECG changes, although other studies ${ }^{10} 11$ have shown that even when women are eligible for thrombolysis they are less likely to receive such treatment. In addition, a greater percentage of women with infarction were admitted to general medical wards where administration of thrombolysis was less.

There was a significantly higher in-hospital mortality for women in both the coronary care unit and the general medical wards. When mortality was considered by age, however, most of these differences were no longer present. For women aged 60-69 years, however, there was still a statistically significant difference and also a trend towards higher in-hospital mortality in women under the age of 60 , although this did not reach statistical significance in either year. Puletti et $a l^{7}$ observed a similar difference in mortality after myocardial infarction for patients aged 56-70 years. They found no explanation for this difference other than the patients gender. In the current study, however, data were not available to permit multiple comparisons.

It has been shown previously ${ }^{124}$ that women presenting with chest pain are proportionately less likely to undergo cardiac catheterisation. Whilst the number of patients undergoing angiography in this series was small, the percentage of women catheterised was significantly less. In women who had sustained an infarct, however, there was no such difference, supporting the view that after infarction women are treated in a similar manner to that of men. ${ }^{12}$

In addition to sustaining myocardial infarctions at an older age, on average, women live 5-8 years longer than men. It could therefore be argued that women should be treated in the same manner as men who are $5-8$ years their juniors. This study has shown that while there is no difference in the treatment of women with myocardial infarction compared to that of men of the same age; there would seem to be some bias in the treatment of older patients, most of whom are women. Treating patients according to their biological rather than their chronological age may not remove the bias in favour of younger, and therefore male, patients, however, it should ensure that all patients irrespective of age and sex are treated appropriately.

\section{Conclusions}

When patients sustaining a myocardial infarction at a similar age are considered there is no difference in the rate of admission to coronary care or administration of thrombolysis between the sexes. Removal of the age limit for admission to the coronary care unit, however, did not alter the proportion of patients with a myocardial infarction admitted to the unit who were female. The difference in inhospital mortality can also probably be explained by the older age of female patients. The application of age limits for admission to coronary care or administration of thrombolysis places elderly patients of both sexes at a 
disadvantage. As women sustain myocardial infarcts at an older age, however, they are placed at a greater disadvantage. Patients should be assessed and treated according to their biological rather than chronological age.

1 Steingart RM, Packer M, Hamm P, Coglinese ME, Gersh B, Geltman EM, for the Survival and Ventricula Enlargement Investigators. Sex differences in the man agement of coronary artery disease. $N$ Engl $f \mathrm{Med}$ 1991;325:226-30.

2 Ayanian JZ, Epstein AM. Differences in the use of procedures between women and men hospitalized for coronary heart disease. N Engl I Med 1991;325:221-5.

3 Petticrew M, McKee M, Jones J. Coronary artery surgery: are wom

4 Kee F, Gaffney B, Currie S, O'Reilly D. Access to coronary catheterisation; fair shares for all? $B M F$ 1993;307: 1305-7.
5 Dittrich H, Gilpin E, Nicod P, Cali G, Henning H, Ross J. Acute myocardial infarction in women: influence of gen1988;62:1-7.

6 Fiebach NH, Viscoli CM, Horwitz RI Differences between women and men in survival after myocardial

7 Wilkinson $\mathrm{P}$, Kooridhottumlcal L, Kulasegaram $\mathrm{R}$, Parsons L, Timmis A. Acute myocardial infarction in women: survival analysis in the first six months. $B M F$ 1994:309:566

8 Greenland $P$, Reicher-Reiss $H$, Goldbourt U, Behar $S$ and the Israeli SPRINT investigators. In-hospital and 1-year mortality in 1,524 women after acute myocardial infarction. Circulation 1991;83:484-91.

9 Second international study of infarct survival collaborative group. Randomised trial of intravenous streptokinase, oral aspirin or both, or neither among 17187 cases of suspected acute myocardial infarction: ISIS 2. Lancet 1988;ii:349-60.

10 Maynard $C$, Althouse $R$, Cerqueira $M$, Olsufka $M$, Kennedy J. Underutilization of thrombolytic therapy in eligible women with acute myocardial infarction. $A m \mathcal{F}$ Cardiol 1991;68:529-30.

11 Maynard C, Litwin P, Martin J, Weaver D. Gender differences in the treatment and outcome of acute myocardial infarction. Arch Intern Med 1992;152:972-6. 